Boise State University

ScholarWorks

Communication Faculty Publications and

Presentations

Department of Communication

$12-1-2014$

\title{
Amending Equal Time: Explaining Institutional Change in American Communication Policy
}

Tim P. Vos

University of Missouri

Seth Ashley

Boise State University 


\title{
Amending Equal Time: Explaining Institutional Change in American Communication Policy
}

\author{
Tim P. Vos \\ Department of Journalism Studies \\ University of Missouri \\ and \\ Seth Ashley \\ Department of Communication \\ Boise State University
}

\begin{abstract}
This study explains the history of a 1959 amendment to the 1934 Communications Act through the lens of historical institutionalism. The amendment created broad exemptions for newscasts, documentaries, interviews and news events when it came to triggering the equal time provision for candidates for public office. While this study offers a variety of new empirical details, the chief goal is explanation based on an examination of historical mechanisms - path dependence, critical junctures, agglomeration, asymmetries of power, reinforcement of expectations, and temporal sequencing - that shaped the policy options leading up to the amendment.
\end{abstract}

The "equal time" provision in U.S. communication policy, or Section 315 of the Communications Act of 1934, provides, under certain conditions, equal opportunities to the airwaves for candidates for public office. The rationale has been that broadcasters can have significant influence over political discourse and election outcomes (Godfrey, 1979; Haines, 1999). But policymakers also have sought to balance an interest in equal opportunities for candidates with broadcasters' First Amendment-derived right to use their own discretion when it comes to deciding what belongs on the air (Napoli, 2001). Thus, the 1959 amendment to the Communications Act of 1934 created broad exemptions for newscasts, documentaries and news events when it came to triggering the equal time provision. Today, the amended provision continues to govern candidate-sponsored political advertising and nonexempt candidate broadcasts. The 1959 exemptions ultimately helped channel political groups into paid political advertising, therein setting the stage for the flood of ads from non-candidate groups during the recent election cycles, especially in the wake of the Supreme Court's Citizens United ruling.

Conventional wisdom suggests that the 1959 amendment simply codified an existing understanding among broadcasters and candidates that the equal time provision only applied to candidate-initiated content in the form of paid advertising or paid speeches (Donahue, 1989; Haines, 1999; Krasnow, Longley, \& Terry, 1982). The amendment came after a complaint by Lar Daly, a fringe candidate in the 1958 Chicago mayoral race, led the Federal Communication Commission to declare that even another candidate's routine appearance on a news program triggered the equal opportunity requirement. The ruling upended the contemporary understanding of equal time, and Congress acted quickly in passing the 1959 amendment. It is clear that Daly was the proximate cause of the passage of the amendment, but not necessarily the historical cause. A sound explanation of the 1959 amendment must consider a broad array of cultural and institutional factors, and also consider the path dependent processes leading up to the Daly decision.

Thus, this study examines historical factors that led to the 1959 amendment and offers an explanation based on an historical institutionalist approach. As a theoretical framework rooted in sociology and political science, historical institutionalism allows for a broad investigation of social, cultural, political and economic contexts that guide the development of patterns of human organization and behavior (Skocpol, 1984). As will be explained below, a focus on historical mechanisms such as path dependence, critical junctures, agglomeration, asymmetries of power, reinforcement of expectations, and temporal sequencing is necessary to explain how policies were adopted or avoided (Hall \& Taylor, 1996; Pierson, 2000). Periods of policy stability are often punctuated by unexpected 
moments of change when paths are selected, alternatives are pushed aside, and winners and losers emerge. This approach can help scholars avoid deterministic or functionalist explanations (Parsons, 2007), which often take intellectual short-cuts and provide oversimplified or unsupported causal explanations.

Institutionalism highlights the nature of contingency surrounding broadcasting policy. The 1959 amendment was one of the few instances of change in the history of political broadcasting policy, which has otherwise reflected a high degree of stability (Haines, 1999). While this study offers a variety of empirical details not discussed elsewhere, the chief goal is explanation based on an examination of historical forces that shaped the policy options that led to the 1959 amendment. This study analyzes a range of primary sources and examines how each of the historical mechanisms mentioned above enters into the explanation for the amendment.

The prevailing accounts of the 1959 amendment rest on the realist or pluralist assumption that self-interested and politically powerful policy actors used their might to get their way. Haines' (1999) chronicle of changes to Section 315 points to the importance of the FCC's Daly decision, whereby broadcasters were told they would be "required to give equal opportunity not only when they provided services at a candidate's request, but also when they covered a news story on their own initiative" (Haines, 1999, pp. 175-176). Finding the FCC decision unworkable, powerful broadcasters simply demanded an amendment to redress the decision. Donahue's (1989) story of the policy change is similar, but suggests that policymakers' self-interests, rather than broadcasters', were the impetus for change. "Congressmen quickly filed a raft of bills to amend Section 315 lest the FCC Lar Daly rule exclude broadcasters from reporting their activities" (Donahue, 1989, p. 56). Krasnow, Longley, and Terry (1982) describe the role of the FCC, the broadcast industry, citizens groups, the courts, and the White House in crafting the amendment, but come to the same conclusions as do Haines and Donahue.

This predominantly descriptive literature offers implicit explanations that rest on pluralist assumptions, taking for granted that "policy choices reflect the relative power of different interests in society," and that policy choices can be understood "by calculating the influence of rival groups" (Dobbin, 1994, p. 5). Policy outcomes in these stories flow more or less directly from powerful agents, namely from commercial, network broadcasters or policymakers. But such pluralist or realist claims are ultimately unsatisfactory; there is more to the story than powerful agents getting their way. Realism is prone to what Pierson calls actor-centered functionalism, i.e., "the claim that a particular institution exists because it is expected to serve the interests of those who created it” (2004, p. 105).

The precise exemptions to Section 315 were debated formally and informally from 1955 to 1960. Generally, policymakers, politicians, and broadcasters debated three options: 1) repealing Section 315, 2) leaving the status quo unaltered, or, 3) creating exemptions to Section 315. All three options had serious, powerful advocates. An explanation of the 1959 amendment must proceed in two steps. First, an explanation must account for how policymakers came to choose exemptions rather than repeal the section or keep the status quo. Second, an explanation must also account for how the four exemptions were selected, while advertising, paid speeches, or other exemptions were not selected.

\section{Background}

In the early years of the American broadcasting experience, a number of viable options for political broadcasting were taking shape (see, Benjamin, 1987; McChesney, 1993). Policy advocates developed options in the 1920s in concert with these emerging practices and consequent concerns about fair access and free speech (see Benjamin 1998;Godfrey, 1979). While largely the same range of policy options appeared in other countries, a unique interaction of values, attitudes, and ideas in the U.S. led to a uniquely American political broadcasting policy (see, Vos, 2010). The 1920s and early 1930s was a critical juncture in the development of American political broadcasting policy. While the array of cultural factors continued to shift in the broader society during the 1940s and onward, little changed in political broadcasting policy. Path dependent mechanisms became more telling than contemporaneous cultural values.

Chicago mayor Richard J. Daley and his Republican challenger dominated the television coverage of the 1958 Chicago mayoral race. Daley would go on to victory in the general election, but a third, long-shot candidate would score a different kind of victory during the campaign. Perennial candidate Lar Daly got only two votes in the election, but he picked up four important votes from the then seven-member FCC in February of 1959 in an appeal 
for equal airtime. WBBM and several other Chicago area broadcasters had run afoul of the equal opportunities provision of the Communications Act. Daly was in the habit of filing complaints with the FCC during his frequent runs for political office (FCC Reports, 1959, p. 717).

Daly’s February 1959 letter to the FCC enumerated nine instances where his Chicago mayoral opponents got airtime and he did not. The FCC agreed with Daly's demand for equal airtime and ordered stations to give Daly airtime (FCC Reports, 1959). However, WBBM’s network parent, CBS, used its considerable power to lobby for change to Section 315. By later that year, Congress had passed and the President had signed an amendment that created a list of exceptions to the section.

The decision provided the first definitive ruling on the form of access to political airtime, but it was not the first time it had been considered. The concept of equal time was initially debated prior to its inclusion as Section 18 in the Radio Act of 1927 (Ostroff, 1980). During hearings in 1926, Ohio Senator Simeon Fess foresaw exactly the problems that would arise with the growth of news and public affairs programming when he asked how the proposed equal opportunities law would apply if "an individual being a candidate for an office ... might be invited to speak somewhere on the occasion of some great celebration where what he was going to say would be broadcasted" (Congressional Record, 1926, p. 12503). The response in 1926 had been that the new commission would have to address such an eventuality with its rulemaking authority. But, broadcasters balked when the FCC finally did address the matter in 1959 and concluded that airtime meant airtime regardless of where the candidate appeared. Fourteen bills were introduced in Congress to address the FCC's ruling (Federal Communication Commission, 1959). Historical mechanisms can be used to analyze these bills that helped produce the eventual policy outcome.

\section{Path Dependence}

At the beginning of a path dependent process is a critical juncture, i.e., a historical moment when various, equally viable paths are open to adoption (Thelen, 2003). The power of path dependence, according to Elster (1989), is rooted in the mechanism of policy feedback or positive feedback. Pierson concludes, "In the presence of positive feedback, the probability of further steps along the same path increases with each move down that path” (2004, p. 21). The history of political broadcasting policy shows at least three distinct forms of positive feedback: agglomeration effects, the creation of asymmetries of power, and the reinforcement of expectations.

Agglomeration. Agglomeration comes from economics and refers to a phenomenon where "initial centers of economic activity may act like a magnet and influence the locational decisions and investments of other economic actors" (Pierson, 2004, p. 25). The concept is adapted here to refer to the support institutions that grew up around private, commercial broadcasting; these included advertising agencies, radio manufacturers and industry organizations, notably the National Association of Broadcasters.

Advertising agencies had initially stayed on the sidelines when broadcasting emerged in the early 1920s. An offer to allow speakers to pay a toll to use AT\&T's WEAF radio booth had landed few takers and produced only \$550 in two months (To weigh, 1925). The breakthrough came when an advertising agency purchased airtime for a product called Mineralava. The purchased airtime included a brief presentation by film actress Marion Davies on "How I make up for the movies" and offered an autographed photo to those who wrote in. The response was overwhelming. Other ad agencies jumped in and advertising took off (see, Sterling \& Kittross, 2002). Advertising agencies that specialized in radio quickly came on the scene. They arranged for airtime and produced programs for broadcasters (see, Barnouw, 1966). These interconnecting activities with existing institutions not only gave commercial broadcasters a superior form of programming, but also created a power base that could not easily be dislodged.

The National Association of Broadcasters also evolved into a support structure for commercial broadcasters. Born out of a radio-licensing dispute, the NAB began as a small association of broadcasters from the West and Midwest. The NAB had been an early supporter of a tax to support broadcasting (Question radio tax plan, 1924) and only later endorsed the move to commercial support. The newly elected president of the NAB in 1926 was Earle C. Anthony, who had entered broadcasting to drum up business for his California car dealership. He helped steer the organization into being an advocate of advertising. The NAB also established "a code of ethics" to rein in advertising excesses (Stations to regulate, 1929, p. 46). The NAB became the chief lobbying arm for broadcasters. 
While delegates to the National Radio Conferences were on record as opposed to intrusive advertising, Commerce Secretary Herbert Hoover had also stated that stations should be free to experiment with advertising: "The listeners will finally decide in any event” (Third National Radio Conference, 1924, p. 4). The decision to make no final decisions about advertising support allowed broadcasting to go down a path it could not easily backtrack. The development of commercial broadcasting had created powerful allies and advocates. Hence, efforts by policymakers to limit advertising on the radio were resisted not only by commercial broadcasters but also by related, entrenched interests (Felix, 1927). The use of advertising to fund the medium exploded in the decades that followed (Sterling \& Kittross, 2002), and it is in this context that the 1959 amendment focused on news content and left political advertising untouched.

Asymmetries of Power. Those realist or pluralist histories of media policy that stress the disproportionate power of corporate, network, or commercial broadcasters are not wrong. Ample historical evidence exists to support a description of powerful broadcast interests crushing their opposition (see, Barnouw, 1966; McChesney, 1993; Rosen, 1980). However, a broader historical framework that accounts for the historical mechanism of an asymmetry of power provides a more nuanced explanation. Politics is such that political authority can be harnessed to create disproportionate power. "Where certain actors are in a position to impose rules on others, the employment of power may be self-reinforcing," according to Pierson. "These changes may not only shift the rules in their favor, but increase their own capacities for political action while diminishing those of their rivals" (Pierson, 2004, p. 36). Such power can accrue to both policymakers and policy advocates outside of government.

The story of path dependence and asymmetries of power must start, not in 1959, but in the 1920s. The Commerce Department, Congress, the radio giants such as GE, RCA, and Westinghouse, and the so-called radio independents, such as the educational, religious, government, and civic broadcasters, opposed direct advertising as a means of support for radio. However, when the Federal Radio Commission decided "[a]dvertising must be accepted for the present as the sole means of support for broadcasting" (Federal Radio Commission, 1929, p. 35), a new broadcast order began to emerge. Likewise, the FRC's General Order 40 used the Commission's authority in the "allocation of frequencies, of time for operation and of station power" (Federal Radio Commission, 1928, p. 48) to up end the hierarchy of stations adopted at early radio conferences called by the Commerce Department (Second National Radio Conference, 1923), and a new commercial broadcast order was being forged.

In 1934, when policymakers revisited how airtime should be allotted in the face of criticism that private, commercial ownership had comprised freedom of speech, General Order 40 had forced all but private, commercial broadcasters off the air (Who owns the air?, 1934). Members of Congress and other politicians, if they were to get airtime for their viewpoints, now had to go through private, commercial broadcasters. In other words, the commercial broadcasters had accrued significant power; an asymmetry of power had been created.

By the 1950s, broadcast networks CBS and NBC, with the help of the NAB - once the NAB's efforts to repeal Section 315 failed to gain support (discussed below) - used their power to lobby for legislative changes. The newly emergent broadcast networks had been accepted by policymakers in 1927 as the means for creating a national radio reach while also maintaining a regional or local distribution of broadcast stations. Senator Robert Howell had worried aloud on the floor of the U.S. Senate that relying on the networks might come with a cost. Howell predicted, "[W]e will wake up some day to find that we have created a Frankenstein monster" (Congressional Record, 1926, p. 12505). The radio networks had expanded to become television networks and the powerful monster was back in 1959 to make its demands.

NBC president Robert Sarnoff brandished the network's power and the power of the broadcast medium in terms policymakers would understand. To require that every candidate be heard, according to Sarnoff, would produce television that would be nearly unwatchable. "Such an exercise in tedium might well destroy public interest in listening even to the major candidates" (Political Broadcasting, 1959, p. 126). If that was not chilling enough to the Senators who Sarnoff addressed, he delivered a thinly veiled threat. "Unless the gag is lifted during the current session of the Congress, a major curtailment of television and radio political coverage in 1960 is inevitable" (Political Broadcasting, 1959, p. 124). The threat was not forgotten: Representative Glenn Cunningham, the first congressman to introduce a bill in 1959 changing Section 315, warned that failure to act would mean a news blackout on radio and television (Rep. Cunningham, 1959). 
It should come as no surprise that some accused the FCC of being in the networks' pockets. Congressional staffer Bernard Schwartz accused the FCC of neglecting the public interest. "Instead, the commission tends increasingly to identify the public with the interests of the dominant groups in the industry to be regulated. The main beneficiaries of this attitude have been the broadcast networks” (Schwartz, 1959, pp. 473-474). The U.S. House had held hearings in 1958 to investigate FCC officials' accepting travel-related expenses from private industry, leading to the resignation of Commissioner Richard Mack (Mack trial, 1959). Schwartz and other critics of the FCC would be vindicated in 1960 when FCC Chairman John Doerfer would be forced to resign for accepting industry gifts (Mr. Doerfer resigns, 1960).

An asymmetry of power is not the whole story. In fact, it is worth emphasizing that the NAB's political broadcast policy preference did not win out. Delegates to a NAB convention in March of 1959 voted for a resolution in favor of repealing 315 (Handicaps, 1959). Chairman Doerfer had told convention delegates, "Some radical revisions or outright repeal proposals seem to be ripe for serious consideration” (That 'ridiculous' ruling, 1959, p. 9). The weekly industry publication Broadcasting produced two editorials in March and another in May calling for repeal of Section 315. Broadcasting laid out the plan of action: "Repeal of Sec. 315 will be achieved only by the most energetic work by broadcasters. They must exercise their most persuasive influences among members of Congress" (315's last legs, 1959, p. 128; see also, Section 315 travesty, 1959). The repeal efforts failed, demonstrating that power asymmetries do not tell the whole story. Indeed, other historical mechanisms were at work in passage of the 1959 Amendment.

Reinforcement of Expectations. Once a policy decision is made, it can have a strong effect on citizens' expectations (Hacker, 2002). In other words, “citizens' basic ways of thinking about the political world will often generate selfreinforcing dynamics” (Pierson, 2004, p. 10). The principle goes beyond politics. Broadcasting practices, once routinized, can also create expectations amongst an audience. When the constitutive battle for a political broadcasting policy was fought in the 1920s and 1930s, the appropriateness of partisan content was not completely settled (Radicals to have, 1925). Granted, neutrality was valued more than partisanship, but the paradigm shift was not complete. Policymakers did not fully expect neutral behavior (Radio Control, 1926) - it had to be legislated as equal opportunities. Likewise, broadcast news was in its infancy and the ethic of objective news was not yet hegemonic as it would be later in the century.

But, the FRC's creation of a broadcast order based on general interest broadcasters produced the expectation that broadcasters would not take sides and would give equal treatment to political voices that represented "all substantial groups among the listening public" (Federal Radio Commission, 1929, p. 34). Politicians either purchased airtime or were invited guests on public affairs programs, such as Town Meeting of the Air and People's Platform. Such programs of the 1930s, which were provided on a free, sustaining basis, could be seen as the equivalent of 1950s TV news interview programs. Broadcasters generally offered public affairs programming that reflected a mix of elite opinion, a practice that carried over as news roundups and newscasts became common during the war years. Policymakers (Radio political, 1944) and regulators continued to nudge broadcasters toward "objectivity in straight news reports" in the 1940s (Fly urges, 1943, p. 15) and the FCC codified balanced news in the Fairness Doctrine in 1949.

While regulators had pushed broadcasters out of partisan coverage and into balanced news and public affairs from the 1920s to the 1940s, by the 1950s broadcasters and audiences alike had come to accept broadcast professionalism as offering a balance of elite political voices (Radio news, 1950). As their popularity grew (Gallup Organization, 1957, Q50), broadcasters hinged their own legitimacy on their commitment to sound editorial judgment. Even TV critics amplified this discourse: "the objectivity and honesty of radio news coverage is one of the most admirable accomplishments of the industry" (Crosby, 1952). Hence, broadcasters were able to appropriate the institutional history of the press as its own. Newspapers used their freedoms to be objective. Broadcasters, the argument went, were no different and should be given the same freedoms (Section 315 travesty, 1959).

Hence, frustrations with Section 315 mounted prior to the 1956 election. CBS took the initiative in 1955 to seek changes to Section 315. CBS President Dr. Frank Stanton's argument was that broadcast journalism should enjoy the same rights as the rest of the press. Broadcasters' news judgment should eliminate the problems of covering minor party candidates that had no chance at elective office (Drummond, 1955; Reston, 1955). CBS proposed to exempt "any news, news interview, news documentary, panel discussion, debate, or similar type program where the format and production of the program and the participants therein are determined by the broadcasting station, or by 
the network in the case of a network program” from Section 315 (Communications Act amendments, 1956, p. 172). Such a change, Stanton argued, would incline broadcasters to give major candidates more airtime via free, news programming.

The argument by Stanton and CBS Vice-President Richard Salant rested on the ethic and practice of objectivity. Broadcast journalists would make sound judgments without bias. Salant assured congressmen that, despite some lawmakers' criticism of broadcasters for playing favorites, there would be no favoritism:

The unspoken premise of this criticism seems clearly to be that in handling news and public affairs functions, a broadcaster, in his role as a part of the press, is so little to be trusted that he must be prevented from exercising any discretion. This is a dangerous premise on which to base legislation (Communications Act amendments, 1956, p. 177-8).

Despite attempts by the networks to paint a drastic picture of limited news coverage of major candidates, policymakers failed to see the urgency for change in 1955. That changed in 1959 with the Daly decision.

Appeals were filed with the FCC in 1959 by WBBM, CBS, WNBQ and NBC, counter-appeals by Daly, and briefs by Westinghouse and the Justice Department in March, April, and May. CBS's appeal was the most extensive. CBS argued: the film clips were run in regular newscasts based on news judgment without any initiative on the part of candidates; Congress did not intend that a news clip could be considered a candidate's 'use' of a broadcasting facility; and broadcast media should have been given the same freedoms as other forms of the press (FCC Reports, 1959). The Justice Department also questioned whether a news story could be considered a use. Justice instead argued that the appropriate standard in the case was the 'public interest,' not 'use' - that the public interest standard should be used to insure that coverage was balanced (see FCC Reports, 1959, p. 719-25). The FCC majority concluded that to accept the broadcasters' arguments would be to change Section 315, something it could not do. The opinion left little doubt that opponents would push for change.

FCC Chairman John Doerfer and Commissioner Fredrick Ford appeared together at the hearings to support change. Ford, who had voted in February that Lar Daly was entitled to equal time, spoke on behalf of the majority of the Commissioners, but now in favor of changing the law. The FCC-backed language read:

Provide that newscasts and special events, such as political conventions shall not be considered a use within the meaning of this section. But this proviso shall not except licensees who broadcast such news and special events from an objective presentation thereof in the public interest (Political Broadcasting, 1959, p. 80).

Doerfer concluded that in the absence of repeal, he endorsed Ford's suggested language. "Broadcasters should be given the right to make the judgment as to what constitutes news” (Political Broadcasting, 1959, p. 82).

Broadcasters also spoke in favor of change. Stanton stated his support for the bill introduced by an Indiana senator because it "relieves broadcasters of the obligation to give equal time to insignificant and fringe candidates" (Political Broadcasting, 1959, p. 97). Stanton argued that such relief would not be abused. He invited congressmen to examine the industry's record of fair reporting. NBC's Sarnoff argued that broadcast journalists were just as objective as newspaper journalists and should be treated no differently (Political Broadcasting, 1959).

The president of the Radio Television News Directors Association, Ralph Renick, argued that times had changed since 1927_- "The industry has disciplined itself over the past 30 years of broadcast history and I doubt if there is any industry more sensitive to the tremor of the public pulse — a sensitivity that makes fair play a cardinal principal from necessity as well as choice" (Political Broadcasting, 1959, p. 237). Renick testified that to treat broadcasters any differently from newspaper publishers was to engage in censorship.

In House hearings later that year, broadcasters again cited their record of providing objective, balanced news coverage. In fact, the FCC testified that it had "one news slanting case in its history" (Political Broadcasts, 1959, p. 97). The expectations for fair and balanced coverage were common. However, agreement about whether broadcasters met the normative standard was less than universal. Minor parties saw things much differently than did mainstream politicians. Lar Daly argued that "the great mistake this industry makes is their attempt to associate 
itself with the fourth estate” (Political Broadcasting, 1959, p. 163) . Aaron Orange, of the Socialist Labor Party, rejected the premise that "in the past candidates of minority parties have actually received equal time and opportunity on radio and television stations, because of the existence of section 315. This is contrary to the facts" (Political Broadcasts, 1959, p. 228). Orange also disputed that broadcasters should be treated like newspapers, since newspapers had ignored his party’s testimony in the Senate hearings (Political Broadcasts, 1959, p. 232).

The 1959 amendment passed in the House and Senate in September. President Eisenhower signed the legislation on September 14, noting that " $(\mathrm{t})$ here is no doubt in my mind that the American radio and television stations can be relied upon to carry out fairly and honestly the provisions of this Act without abuse or partiality to any individual, group, or party" (U.S. President, 1960, p. 654).

An expectation that broadcasters would be honest and impartial was limited in the 1920s, but by the 1950s, the expectation had become part of the institution. At the same time, the expectation for fairness and balance must also be recognized as a factor that limited the demands of powerful broadcast interests and helped preserve the equal opportunities provision of the political broadcasting policy adopted in the 1920s.

\section{Sequencing}

Path dependence is built on the notion that the sequence in which things happen makes a difference. In Shefter's (1994) classic comparison of bureaucracy and democracy, timing is of critical importance. "The sequence in which these two events occur-the formation of a constituency for bureaucratic autonomy and the mobilization of a mass electorate- thus has enduring consequences for internally mobilized parties" (Shefter, 1994, p. 31). Pierson cites Shefter's argument as a prototypical case of how the order "of sequences of social events and processes" affects historical outcomes (2004, p. 64).

One example of the importance of sequencing in political broadcasting policy came in the timing of a political broadcasting policy when broadcast news was still not developed in the American broadcast experience. The U.S. policy, written in 1927 and left unaltered in 1934, came at a time when broadcast news was not fully developed. In fact, radio as a news medium had been stunted by some unique circumstances.

Secretary Hoover had used the bully pulpit of the Third National Radio Conference in 1924 to urge reluctant broadcasters to develop a broadcast service offering audiences the chance to listen in to national events (Third National Radio Conference, 1924). And while Hoover suggested such a service should be modeled after the press news services, he was not explicit that such a service would present news as an edited summary of events. Such news summaries were rare, even at stations owned by newspapers. The Associated Press and newspapers bore some responsibility for the dearth of broadcast news. AP had a policy of denying its wire services to radio stations (A.P. modifies ban, 1925). Meanwhile, the American Newspaper Press Association (ANPA) did what it could to stunt the development of broadcast news (Publishers see need, 1931; Radio head defends, 1931). Even the resolution of the tensions between the ANPA and broadcasters was a blow to broadcast news. The Biltmore agreement called for radio networks and several independent stations to dismantle their upstart news operations and air press service news bulletins twice a day after morning and afternoon papers had been delivered (Radio news plan, 1933; Radio news plan, 1934).

By the 1940s news would become an important part of radio. In fact, historians have argued that radio surpassed newspapers as America's news medium during World War Two (Barnouw, 1966). Building on experience gained in radio, television broadcasters also formed news departments to cover political events, produce newscasts, and create news documentaries. Television coverage of the Democratic and Republican Party conventions, begun in 1948, had become a staple of political broadcasting by 1956. After the 1948 conventions CBS-TV launched a daily newscast and by the late 1950s, not only did each network produce a newscast, but many local TV stations, such as WBBM, WGN, and WNBQ in Chicago, produced their own local newscasts. Broadcast news had also come to embrace the institutional heritage of the press, adopting routines of objectivity; i.e., attempting to present factual information that was balanced and fair to different partisan interests (see, Sterling \& Kittross, 2002). As noted above, the FCC had adopted the normative expectation that news would be reported "fairly, objectively and without bias" (Mayflower broadcasting corp., 1941, p. 339). 
So, why is timing or sequencing important here? Section 18 of the Radio Act and its clone, Section 315 of the Communications Act, did not directly address news. Given the stunted growth of radio news in the U.S., that should come as no surprise. The political broadcasting regulations that emerged in the late 1920s and 1930s attempted to extend some of the logic of Sections 18 and 315 to news, but the approach was piecemeal. The Fairness Doctrine had been formalized in 1949, but it did not answer all of broadcasters' concerns. Broadcasters struggled to know how to treat candidates in news broadcasts, particularly the so-called minor candidates. As noted above, CBS sought to create clarity in 1955 by pushing for changes to Section 315 that would exempt news. CBS ran into resistance and policymakers were forced to revisit the goals of a political broadcasting policy and how news fit into those goals.

But with path dependent processes at work, it was difficult to turn back the calendar for a full consideration of the role of broadcasters in republican governance. For example, in 1956 Texas Congressman Walter Rogers questioned whether giving broadcasters editorial control over who should receive airtime was healthy for a representative democracy.

If you don't permit a man to be seen by the public, although he may be the best presidential candidate or the best candidate for district attorney, if he is not allowed to be seen on television and he cannot get free time and he doesn't have the money to buy time, how in the world is the public going to be rendered a service if they are given only a choice between, we will say, Republican and Democratic candidates, both of whom may be scoundrels (Communications Act amendments, 1956, p. 187).

Policymakers, broadcasters, and commentators showed little interest in tackling such questions. Less than three years later, following the FCC's Lar Daly decision, such questions were also given short shrift. But the conditions under which the questions would be posed were also much different than in 1927. At least two major changes had created new conditions: the ethic of objective news and the Fairness Doctrine.

Legitimating claims about the objectivity of broadcast journalists would have been unlikely in the 1920s. Not only was broadcast journalism itself in its infancy, journalistic objectivity was only emerging as a normative press ethic in the 1930s (see, Schudson, 2001). CBS's Richard Salant had responded to Representative Rogers' question about denying coverage to some candidates by assuring the congressman that broadcasters would act objectively, with suitable editorial judgment (Communications Act amendments, 1956). Such a response in the 1920s would have held little real meaning or authoritative weight.

Following the Daly decision in 1959, policymakers raced to change Section 315, but did so with full awareness of the FCC's Fairness Doctrine. In the Senate committee report on the bill, the writers made it clear that even though news was being made exempt from Section 315, the Fairness Doctrine would prevent abuses. "Fear has been expressed that the adoption of legislation creating special categories of exemptions from section 315 would tend to weaken the present requirement of fair treatment of public issues” (Sen. Rep. No. 562, 1959, p. 13). However the report concluded that just the opposite was the case. The new law would both validate the FCC's policy and rely on it to assure the fairness of news about political actors. When the amendment passed it included the following language:

Nothing in the foregoing sentence shall be construed as relieving broadcasters, in connection with the presentation of newscasts, news interviews, news documentaries, and on-the-spot coverage of news events, from the obligation imposed upon them under this Act to operate in the public interest and to afford reasonable opportunity for the discussions of conflicting views on issues of public importance (Communications Act, 1959).

For a time, the courts held that the 1959 Amendment had actually codified the Fairness Doctrine. The Supreme Court's Red Lion decision in 1969 concluded, "Congress has not just kept its silence by refusing to overturn the administrative construction, but has ratified [the Fairness Doctrine] with positive legislation” (Red Lion, 1969). While the courts would later allow the FCC to repeal the Fairness Doctrine, the point remains that policymakers in 1959 had made a change to Section 315 with the understanding that newscasts would be required by the FCC to abide by the Fairness Doctrine. While counterfactuals lack unambiguous empirical support, if the Fairness Doctrine 
had not been in play, policymakers would have faced a significantly different dynamic. If the creation of exemptions to Section 315 had been considered in a different sequence of events-for example either before the creation of the Fairness Doctrine or after its repeal—the policy outcome may have been affected.

\section{Conclusions}

A variety of historical mechanisms are helpful in understanding and explaining the 1959 amendment to the Communication Act of 1934, and the historical institutionalist framework employed here is a useful approach for scholars who wish to study how policies were adopted or avoided. The debate over the 1959 amendment represents a moment of contingency, relatively rare in the history of broadcasting policy, making this a subject worthy of analysis that reaches beyond realist, pluralist, or functionalist explanations. The focus on path dependence, critical junctures, agglomeration, asymmetries of power, reinforcement of expectations, and temporal sequencing is key to richer theoretical explanation.

The 1959 amendment - as opposed to full repeal of Section 315 or no action at all - was the likely policy outcome based on a consideration of path dependent processes initiated by the 1927 Radio Act and the 1934 Communications Act. Lasting effects could be felt from these earlier policy decisions, such as General Order 40, to give preference to the emerging commercial broadcasting industry and to support agglomerated power in the industries that grew up around the broadcasting giants. Power asymmetries had been created in earlier efforts to marginalize less powerful voices such as amateurs, universities, and religious and political groups. The 1959 question of how to deal with Section 315 represents a moment of contingency, evidenced by the FCC's rulings and congressional pushback against broadcasters, not to mention the concerns expressed by minority parties.

A policy script was already in the works, thanks to the 1955 exemption proposed by CBS, even though it did not pass at the time. The organized, asymmetrical power of the National Association for Broadcasters, not to mention veiled threats by NBC's Sarnoff to cease coverage of politics, energized the push for repeal, but full repeal was tempered by an apparent desire in Congress to do no more than necessary. Expectations surrounding the creation of exemptions for news were reinforced rather than altered.

Ultimately, it is not enough to point to a key decision, such as the Lar Daly ruling, or to point to congressional selfinterest and construct an adequate explanation of the 1959 amendment. More than anything, the amendment highlights the shifting institutional foundations for the Communications Act, bringing into focus the underlying assumptions that were the subject of challenge in 1959. Looking forward, media policy scholars and historians should make use of the historical institutionalist approach as they examine other communication policy outcomes and seek to understand our current critical juncture in U.S. media policy. 


\section{References}

315's last legs. (1959, March 23). Broadcasting, 23, 128.

A.P. modifies ban on broadcast news. (1925, April 23). New York Times, p. 8.

Barnouw, E. (1966). A history of broadcasting in the United States. New York: Oxford University Press.

Benjamin, L. M. (1987). Broadcast campaign precedents from the 1924 presidential election. Journal of Broadcasting and Electronic Media, 31(4), 449-460.

Benjamin, L. (1998). Working it out together: Radio policy from Hoover to the Radio Act of 1927. Journal of Broadcasting \& Electronic Media, 42(2), 221-236.

Communications Act, 47 U.S.C. $\S \S 315$ (1959).

Communications Act amendments: Hearings before the Committee on Interstate and Foreign Commerce, House of Representatives, 84th Cong., 2nd Sess. (1956).

Congressional Record, 69th Cong., 1st Sess. (1926).

Congressional Record, 86th Cong., 1st Sess. (1959).

Crosby, J. (1952, November 7). New suppression, Pittsburgh Post-Gazette, p. 34.

Dobbin, F. (1994). Forging industrial policy: The United States, Britain, and France in the railway age. New York: Cambridge University Press.

Donahue, H. C. (1989). The battle to control broadcast news: Who owns the First Amendment? Cambridge, MA: MIT Press.

Drummond, R. (1955, June 8). TV, campaign and voters, New York Herald Tribune.

Elster, J. (1989). Nuts and bolts for the social sciences. New York: Cambridge University Press.

FCC Reports. (1959). Interpretative opinion re: Section 315 of the Act. Washington, D.C.: Federal Communications Commission.

Federal Communication Commission. (1958). 24th annual report. Washington, D.C.: Government Printing Office.

Federal Communication Commission. (1959). 25th annual report. Washington, D.C.: Government Printing Office.

Federal Radio Commission. (1928). Second annual report of the Federal Radio Commission to the Congress of the United States. Washington, D.C.: Government Printing Office.

Federal Radio Commission. (1929). Third annual report of the Federal Radio Commission to the Congress of the United States. Washington, D.C.: Government Printing Office.

Felix, E. H. (1927). Using radio in sales promotion: A book for advertisers, station managers and broadcasting artists (1st ed.). New York: McGraw-Hill Book Company.

Fly urges 'uncolored' radio news broadcasts. (1943, September 13). Reading Eagle, p. 15.

Gallup Organization. (1957, May 22). Gallup Poll, Q50.

Godfrey, D. G. (1979). Senator Dill and the 1927 Radio Act. Journal of Broadcasting, 23, 477-490.

Hacker, J. S. (2002). The divided welfare state: The battle over public and private social benefits in the United States. New York: Cambridge University Press.

Haines, J. V. (1999). Political Broadcasting Amendments to the Communications Act of 1934. In M. D. Paglin, J. R. Hobson \& J. Rosenbloom (Eds.), The Communications Act : a legislative history of the major amendments, 1934-1996 (pp. 174-180). Silver Spring, MD: Pike \& Fischer.

Hall, P. A., \& Taylor, R. C. R. (1996). Political science and the three new institutionalisms. Political Studies, 44(5), 936-957.

Handicaps. (1959, March 23). Broadcasting, 23, 34.

Krasnow, E. G., Longley, L. D., \& Terry, H. A. (1982). The politics of broadcast regulation (3rd ed.). New York: St. Martin's Press.

Mack trial witness parade is underway. (1959, April 27). Broadcasting, 66.

Mayflower broadcasting corp. (1941). FCC Reports. Washington, D.C.: Federal Communications Commission.

McChesney, R. W. (1993). Telecommunications, mass media, and democracy: The battle for the control of U.S. broadcasting, 1928-1935. New York: Oxford University Press.

Mr. Doerfer resigns. (1960, March 11). New York Times, p. 1.

Napoli, P. M. (2001). Foundations of communications policy: Principles and process in the regulation of electronic media. Cresskill, NJ: Hampton Press.

Ostroff, D. H. (1980). Equal time: Origins of Section 18 of the Radio Act of 1927. Journal of Broadcasting, 24(3), 367-380.

Parsons, C. (2007). How to map arguments in political science. New York: Oxford Press.

Pierson, P. (2000). Increasing returns, path dependence, and the study of politics. American Political Science Review, 94(2), 251-267. 
Pierson, P. (2004). Politics in time: History, institutions, and social analysis. Princeton, NJ: Princeton University Press.

Political Broadcasting: Hearings before the Committee on Interstate and Foreign Commerce, U.S. Senate, 86th Cong., 1st Sess. (1959).

Political broadcasts-Equal time: Hearings before the Committee on Interstate and Foreign Commerce, U.S. House, 86th Cong., 1st Sess. (1959).

Publishers see need for curb on radio. (1931, April 23). New York Times, p. 14.

Question radio tax plan. (1924, August 19). New York Times, p. 13.

Radicals to have a radio station. (1925, September 25). New York Times, p. 25.

Radio control: Hearings before the Committee on Interstate Commerce, U.S. Senate, 69th Cong., 1st Sess. (1926).

Radio head defends news broadcasts. (1931, April 25). New York Times, p. 11.

Radio news plan ends long fight. (1933, December 16). New York Times, p. 18.

Radio news plan in effect today. (1934, March 1). New York Times, p. 16.

Radio news survey shows popularity. (1950, April 18). Spokane Daily Chronicle, p. 20.

Radio political broadcasts face senate inquiry. (1944, November 5). St. Petersburg Times, p. 34.

Red Lion Broadcasting v. Federal Communications Commission, 395367 (Supreme Court of the United States 1969).

Rep. Cunningham plans Sec. 315 bill. (1959, March 9). Broadcasting, 76.

Reston, J. (1955, May 26). Radio, TV and 1956--An account of the new difficulties facing broadcasters in the campaign, New York Times.

Rosen, P. T. (1980). The modern stentors: Radio broadcasters and the federal government, 1920-1934. Westport, CT: Greenwood Press.

Schudson, M. (2001). The objectivity norm in American journalism. Journalism, 2(2), 149-170.

Schwartz, B. (1959, May 23). The 'sick' commission: FCC and the networks. The Nation, 473-474.

Second National Radio Conference. (1923). Recommendations of the National Radio Committee. Washington, D.C.: Government Printing Office.

Section 315 travesty. (1959, March 9). Broadcasting, 23, 142.

Senate Report No. 562, 86th Cong., 1st Sess. (1959).

Shefter, M. (1994). Political parties and the state: The American historical experience. Princeton NJ: Princeton University Press.

Skocpol, T. (Ed.). (1984). Vision and method in historical sociology. New York: Cambridge University Press.

Stations to regulate radio advertising. (1929, March 26). New York Times, p. 46.

Sterling, C. H., \& Kittross, J. M. (2002). Stay tuned: A history of American broadcasting (3rd ed.). Mahwah, NJ: Lawrence Erlbaum Associates.

That 'ridiculous' Lar Daly FCC ruling. (1959, March 23). Broadcasting, 23, 9.

Thelen, K. (2003). How institutions evolve. In J. Mahoney \& D. Rueschemeyer (Eds.), Comparative historical analysis in the social sciences (pp. 208-240). New York: Cambridge University Press.

Third National Radio Conference. (1924). Recommendations for Regulation of Radio (pp. 35). Washington, D.C.: Government Printing Office.

To weigh the radio for advertisers. (1925, April 25). New York Times, p. 25.

U.S. President. (1960). Public Papers of the Presidents of the United States, Dwight D. Eisenhower, 1959. Washington, D.C.: United States Government Printing Office.

Vos, T. P. (2010). A cultural explanation for early broadcast policy: Professionalism, voluntarism, and U.S. Broadcast Networks. Journal of Broadcasting \& Electronic Media, 54(2), 179-193.

Who owns the air? (1934, August 22). The Nation, 139, 201. 